\title{
MASS HOUSING ESTATES IN CSEPEL, BUDAPEST: URBAN FORM EVALUATION IN RELATION TO SUSTAINABILITY
}

DOI: 10.18485/arh_pt.2020.7.ch3

\author{
_ Hlib Antypenko \\ PhD student, Csonka Pál Doctoral School, Faculty of Architecture, \\ Budapest University of Technology and Economics, H-1111 Budapest, \\ Múegyetem rkp. 3, hlib100694@gmail.com

\section{_ Melinda Benko} \\ PhD and habil., Associate Professor, Department of urban Planning and Design, \\ Faculty of Architecture, Budapest University of Technology and Economics, \\ H-1111 Budapest, Mǔegyetem rkp. 3, benko@urb.bme.hu
}

\begin{abstract}
Mass housing is a global urban phenomenon, whilst in the Central and Eastern European countries the majority of these neighborhoods were constructed during the socialist period. The research focuses on the city of Csepel, former industrial town, since 1950 the $21^{\text {st }}$ district of Budapest. Budapest is one of the Hungarian cities with a very high mass housing ratio, more than two-third of its population lives there. The paper compares five housing developments in Csepel - three of them were awarded on a national level at the time of their construction. Situated next to the main axis of Csepel - Béke téri, a modern housing estate from the end of 40s; Rakéta utcai, an awarded modern housing estate from the end of 50s; Ady út large prefabricated housing estate with 10 story high slabs from the end of 60s; Simon Bolivár Estate, an awarded large prefabricated housing estate from the end of 70s; and Rákóczi úti - one of the rare social housing developments from 2000s in Hungary.

The urban position of these neighborhoods is similar, while the architectural and technical qualities of the buildings vary and is often subjected to the original construction problems or actual renewal policy issues. Taking into consideration that all these estates were planned as a single urban and development unit, its urban form and open space elements should be revaluated, seeking the perspectives for its adaptation to the contemporary urban and market demands. Comparison uses sustainability indicators related to physical environment such as: density, diversity, land use, greening, transportation, compactness et cetera to give a fair picture of the estates' urban values and potentials. What are the architecture and urban qualities and weaknesses of these housing estates? How the urban form developed over time? How sustainable is the urban form of these estates? What can be done to boost its attractiveness to the citizens, architects, and developers?
\end{abstract}

KEYWORDS _ mass housing, urban form, sustainable urban neighborhoods, post-socialist city, Budapest

\section{INTRODUCTION}

Located in the south of Budapest outskirt, separated from the city by the waters of Danube river, the $21 \mathrm{st}$ district of Budapest, Csepel is now a reservation of middle-class mass housing estates constructed mainly in the after-WWII period. From the 9th century Csepel used to be one of the firsts 
Hungarian settlements in the Carpathian Basin, remaining a small village thereafter. Csepel urban development started with the 19th century industrialization, and finally it became the land of "Manfred Weiss Steel and Metal Works". Nevertheless, industrial town and mass housing are mandatory interconnected. In the in-between period of WWI and WWII, factories provided workers, officers, and engineers with the new neighborhoods for living. Shortly after the end of the WWII, in 1949, Hungary became a satellite state of the Soviet Union. The Hungarian capital city of Budapest was transformed, Csepel became a district of a "big" Budapest realized in 1950, and "Csepel Works" functioned as the biggest socialist urban factory (Benkő \& Kissfazekas, 2019). This dramatic political, economic, and social change determined the development of Hungarian cities and housing for the next 40 years. Public mass housing program started under the motto of building "better, faster, and cheaper" in all the socialist states of Eastern Europe (Engel, 2019). Nevertheless, among all post-socialist countries, Hungary remained the land of "small" housing estates. As of today, only one fifths of the Hungarians and one third of Budapest's population lives in panel houses (Kovács et al. 2018). In Csepel, however, this ratio is much higher, approximately, two-third of the actual population lives in privately owned flats of inherited modern large prefabricated housing estates (Clapham, 1995). The paper compares five mass housing developments (fig. 1), built in different time periods after WWII, using different planning ideas and technology. This approach helps to understand how the planning and urban design concepts of the selected estates evolved during the time, how it affected urban form, and what are the potentials to adapt these estates to a more sustainable future. Assuming that these modern buildings and neighborhoods will remain for a long time, they should be considered as an integrated, well recognized part of contemporary Budapest, not just a hidden and stigmatized heritage (Benkő, 2015).

\section{SELECTION OF CSEPEL CASE STUDIES}

The construction of the first modern housing estate in Csepel, the Béke tér (No1) began in 1948 as a new home for 4000-6000 top workers of Csepel factories (fig.1). Not long after this, in the mid-50s, Rakéta utcai (No2), a formerly agricultural land became the new development area for mass housing. The masterplan and several residential buildings for this area were designed by the Hungarian architect Lajos Zalaváry, awarded with the most important Hungarian architecture prize, the YblPrize in 1956 (Barna et al., 1995). It's worth mentioning that before introduction of panel technology in the early 60s, most of the multi-family houses in Csepel were low-rise (3-5 story high) buildings made of bricks. Traditional technology, small flats, and well-established greenery characterize these housing estates. However, after 1965, with the opening of the first big panel factory in Budapest, the 10 story-high slabs became a general building typology. This can be seen in the Ady housing estate (No3), where Soviet and Danish panel technologies were used to construct a homogeneous highrise neighborhood with some residential towers exceeding 15 -storey height. The new development phase of Csepel started at the end of 70s, evidently using the same panel technology for mass housing. Simon Bolivar housing estate (No4) introduced a new urban form varying 10 and 4 story-high buildings organized in a superblock frame (Petz, 2017). In 1979 the Teréz P. Ürmössy masterplan design for this estate received the Ybl-Prize, as well.

The Rákóczi block (No5), the last case for comparison was realized after the change of the political and economic regime. It was one of the few contemporary Hungarian housing projects to be constructed at that time. The block itself is a result of an infrastructure development was divided into three plots: the middle plot is municipality initiated social housing project from 2004, the Southern part constructed by a private investor is a residential complex finished in 2012, and the Northern part, which 20 years after still remains a vacant land for further development. 

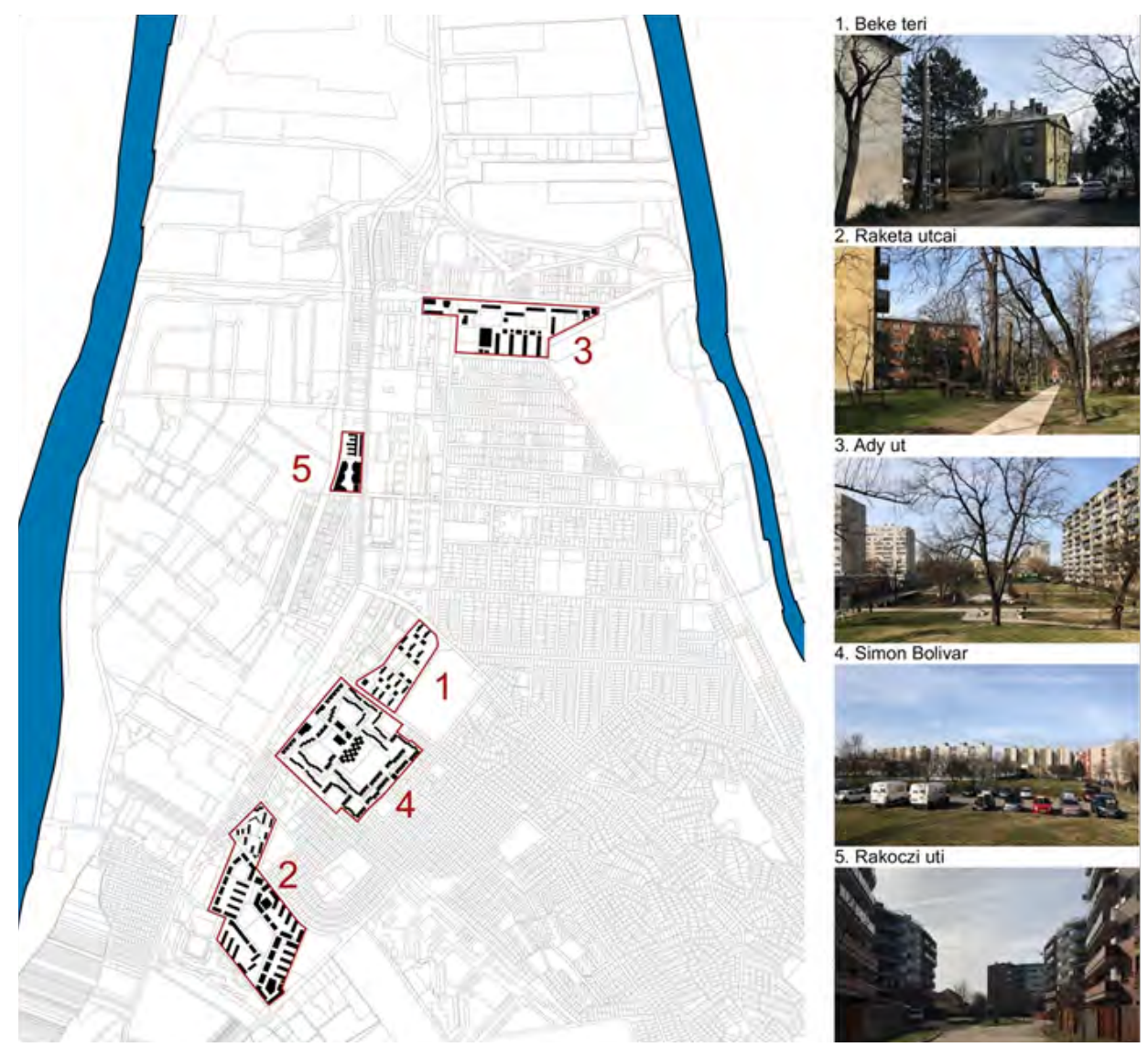

_ Figure 1: Case studies area in Csepel. Red - the boundary of a housing estate; blue - Danube river. The numbering follows the chronological order. Source: Author

\section{METHOD}

Around the time when mass housing in Europe got its first criticism and to the point when in some countries of Western Europe, it was stopped as a practice, the discourse about sustainability as a response to the forthcoming global challenges appeared in the social and scientific realm. Literary works of Hough (1984), Calthorpe (1993), Frey (1999) are among the first to try to connect ecological and social threats with the urban development. While sustainability is a broad term used in many aspects of human life, the link between sustainability and urban design is well established and is primarily based on the effect of urban form on transport, water quality and recharge rates, habitat, equity concerns, and pollution. Following the sustainable urban design framework matrix, urban form of the five selected housing estates of Csepel is analyzed on its relation to five components of the sustainability: energy use/GHG, water quality and recharge, ecology/habitat, energy use/production, equity and health (Larco, 2015). For the purpose of this paper, only elements that are directly affecting urban form are analyzed and compared (Table 1). It is worth mentioning that in the framework developed by Larco (2015) urban elements are grouped by 4 scales: regional, district, street/ block, and project/parcel. While in Larco's study splitting elements by scales aims to help urban designers to connect it to the actual area of intervention, for the purpose of this paper, the scaling distinction is not used. 
- Table 1: Urban design elements grouped by sustainability components

\begin{tabular}{|c|c|c|c|c|}
\hline Energy use/GHG & $\begin{array}{l}\text { Water quality } \\
\text { And recharge }\end{array}$ & $\begin{array}{l}\text { Ecology/ } \\
\text { habitat }\end{array}$ & $\begin{array}{l}\text { Energy use/ } \\
\text { production }\end{array}$ & Equity \& health \\
\hline $\begin{array}{l}\text { 1. Small and defined } \\
\text { blocks } \\
\text { 2.High building } \\
\text { /housing density } \\
\text { 3.Multimodal street } \\
\text { design } \\
\text { 4.High land use mix } \\
\text { 5.Micro-parking } \\
\text { design } \\
\text { 6.Platting for density } \\
\text { (quality of urban } \\
\text { planning) }\end{array}$ & $\begin{array}{l}\text { 7.High surface } \\
\text { permeability }\end{array}$ & $\begin{array}{l}\text { 7.High surface } \\
\text { permeability } \\
\text { 8.High urban } \\
\text { forest } \\
\text { continuity/ } \\
\text { diversity }\end{array}$ & $\begin{array}{l}\text { 9.Dense/energy } \\
\text { efficient building } \\
\text { typologies } \\
\text { 2.High building } \\
\text { housing density } \\
\text { 10.Block size/street } \\
\text { orientation for } \\
\text { microclimate } \\
\text { mitigation }\end{array}$ & $\begin{array}{l}\text { 11.Active/attractive } \\
\text { open space } \\
\text { 12.Mix of unite } \\
\text { types } \\
\text { 8.Urban forest and } \\
\text { robust vegetation } \\
\text { 4.High land use mix }\end{array}$ \\
\hline
\end{tabular}

The research uses international literature, but comparison data is based on local experience gained by the field work. The most objective data was achieved from mapping. The goal was to collect information about the actual density and the proportion of built, green, and paved area of each estate. According to Table 1, density parameter is directly connected to at least two sustainability components. Both energy use GHG and production are dependent on urban form density. Whereas density is rather a complex criterion and by many theorists is separated into at least housing, building, and human density, for the purpose of this research, only the building density was measured. Salat (2011) defines building density as a ratio of floor area of all buildings to the plot area to which it belongs. Another important parameter that this paper explores, is the ratio of built, green, and paved area. This data is important to evaluate the sustainability of water usage, ecology impact, equity and health of the districts. Mapping, however, is limited to measure urban elements such as active/ attractive open space, affordability of housing, multimodal street design, mix of unite types etc. For this purpose, additional data from literature sources and personal observations of the site were used. Finally, a relative ranking 1-5 (table2) helped the classification.

\section{DENSITY AND RATIO OF BUILT, GREEN, AND PAVED AREA: ANALYSIS AND RESULTS}

This paragraph presents the results of comparative analysis of space type and density of the 5 housing estates of Csepel. All the maps (fig. 3) and graphs (fig. 2) are shown in chronological order, starting with the oldest estates up to the most recent one.

By looking at the actual maps of five housing estates of Csepel (fig.3), it becomes evident that the first 4 estates from socialist time present a continues homogeneous urban environment with distinctive master plans. The dominance of publicly owned green space and its continuity is also a characteristic factor for these estates (fig.2). The earliest developments, the Béke tér and the Rakéta utcai housing estates are somewhat representations of the "garden city", human scaled concept with low-rise buildings. In the meantime, the Béke tér presents a modern masterplan composed mainly by "slabs and cubes" elements. Some years later, the Rakéta utcai redesigns traditional urban form with slabs being adjacent to the street lines and dominance of open courtyards. Ady úti estate from the end of 60 s can be more referred to the international "TeamX concept" of the 11-storey high-rise buildings floating in a vast area of green city park. The next by chronology Simon Bolivar estate refers to the well-spread in the Soviet Union urban typology of micro-districts. It has a clear, symmetrical urban structure forming a frame with a closed perimeter of residential buildings and some commercial functions, whereas the center of the estate is a less dense space with public buildings like a school and a day care center. The most obvious difference in both space ratios and density (fig.2) belongs to the newest housing development of Rákóczi block. It is visibly the smallest housing area from all 5 , with characteristically different urban form. The area is private and fenced, 
and both housing projects of the block create fragmented volumes with huge paved areas for parking facilities without providing ecological continuity typical for the former socialist developments. As a result, the estate is $100 \%$ more dense than its predecessor Simon Bolivar from the 70 s, it is also $80 \%$ less green than the first housing estate of Béke téri from the end of 40 s.

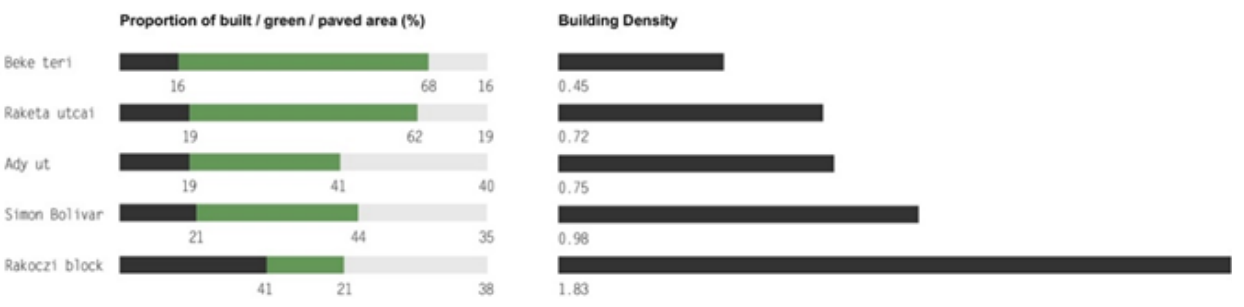

_ Figure 2: Comparison results. Source: Author

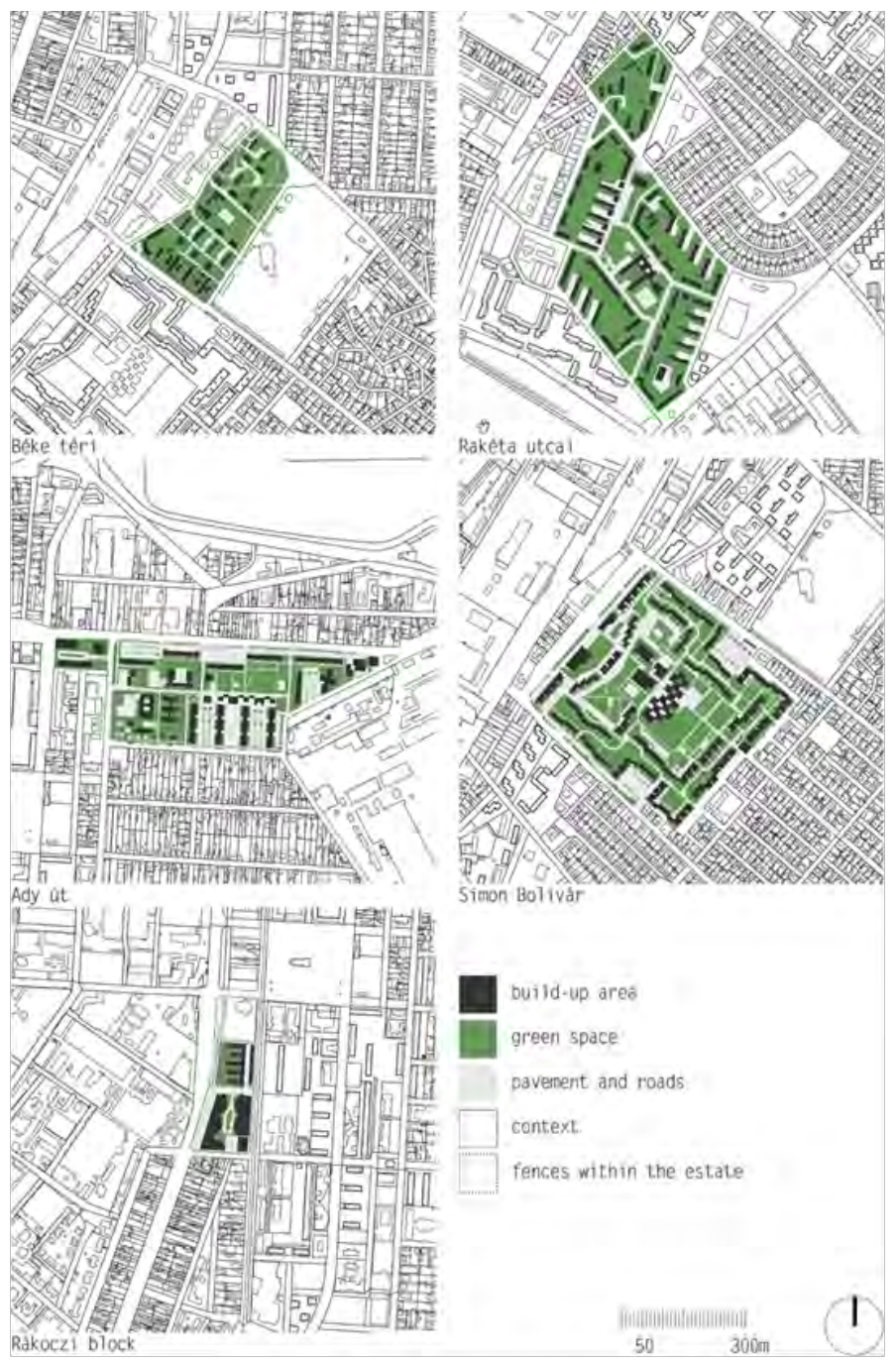

_ Figure 3: Urban form analysis of the five housing estates of Csepel district. Source: Author 
What is also apparent from the comparison results (fig.2), is the growing density of the buildings and reduction of green space over the time span. The ratio of built area stays almost the same, while the green space is slowly being taken by paved areas in all socialist time estates. This leads us to the preliminary conclusion that with the time denser urban developments were to be seen as more efficient, and the shift towards the use of parking spaces instead of preserving green is directly connected to the growing density. Nevertheless, the differences in density and proportions of green, paved, and built land don't give us definite answers about actual sustainability of these estates (Poklewski-Koziell, 2015). While dominance of green spaces and low density in socialist estates can be good for sustainable components like water recharge and ecology/habitat, the high density of the newest development of Rákóczi block is a good indicator for both energy use/GHG and production. It is also sure that some of the urban design elements cannot be accessed by the indicators of density and space types. Therefore, site visits and personal observations were used as an additional assessment method.

\section{EVALUATION OF THE URBAN FORM IN RELATION TO SUSTAINABILITY}

In order to answer the question, which mass housing estate and what urban form has more sustainable parameters, the research created an objective method. Table2 uses a relative ranking (1 least -5 most) of the five estates (based on calculations and in-situ observations) for each of the sustainability components presented in table1, with total scores given at the end.

_ Table 2: Evaluation of urban form elements in relation to sustainability. Where 5 and 1 point are the most and least sustainable results

\begin{tabular}{|l|c|c|c|c|c|}
\hline & $\begin{array}{c}\text { Béke } \\
\text { téri }\end{array}$ & $\begin{array}{c}\text { Rakéta } \\
\text { utcai }\end{array}$ & Ady úti & $\begin{array}{c}\text { Simon } \\
\text { Bolivar }\end{array}$ & $\begin{array}{c}\text { Rákóczi } \\
\text { block }\end{array}$ \\
\hline 1. Small and defined blocks & $\mathbf{4}$ & $\mathbf{3}$ & $\mathbf{2}$ & $\mathbf{1}$ & $\mathbf{5}$ \\
\hline 2. High building/housing density & $\mathbf{1}$ & $\mathbf{2}$ & $\mathbf{3}$ & $\mathbf{4}$ & $\mathbf{5}$ \\
\hline 3. Multimodal street design & $\mathbf{4}$ & $\mathbf{5}$ & $\mathbf{3}$ & $\mathbf{2}$ & $\mathbf{1}$ \\
\hline $\begin{array}{l}\text { 4. High land use mix (functional mix of the housing } \\
\text { estate) }\end{array}$ & $\mathbf{1}$ & $\mathbf{4}$ & $\mathbf{3}$ & $\mathbf{5}$ & $\mathbf{2}$ \\
\hline 5. Parking design & $\mathbf{2}$ & $\mathbf{4}$ & $\mathbf{1}$ & $\mathbf{3}$ & $\mathbf{5}$ \\
\hline 6. Platting for density & $\mathbf{1}$ & $\mathbf{3}$ & $\mathbf{2}$ & $\mathbf{4}$ & $\mathbf{5}$ \\
\hline 7. High surface permeability & $\mathbf{5}$ & $\mathbf{4}$ & $\mathbf{2}$ & $\mathbf{3}$ & $\mathbf{1}$ \\
\hline 8. High urban forest continuity/diversity & $\mathbf{5}$ & $\mathbf{4}$ & $\mathbf{2}$ & $\mathbf{3}$ & $\mathbf{1}$ \\
\hline $\begin{array}{l}\text { 9. Dense/energy efficient building typologies (if we } \\
\text { imagine renovation of every building) }\end{array}$ & $\mathbf{1}$ & $\mathbf{2}$ & $\mathbf{1}$ & $\mathbf{3}$ & $\mathbf{5}$ \\
\hline 10. Block size/street orientation & $\mathbf{4}$ & $\mathbf{2}$ & $\mathbf{1}$ & $\mathbf{5}$ & $\mathbf{3}$ \\
\hline 11. Active/attractive open space (actual condition) & $\mathbf{1}$ & $\mathbf{3}$ & $\mathbf{5}$ & $\mathbf{4}$ & $\mathbf{2}$ \\
\hline 12. Mix of unit types (buildings) & $\mathbf{3}$ & $\mathbf{4}$ & $\mathbf{1}$ & $\mathbf{5}$ & $\mathbf{2}$ \\
\hline Total & $\mathbf{3 2}$ & $\mathbf{4 0}$ & $\mathbf{2 6}$ & $\mathbf{4 2}$ & $\mathbf{3 6}$ \\
\hline
\end{tabular}

As mentioned before, some of the urban design elements can be easily evaluated from the analysis data (fig.2). For instance, when we talk about high building/housing density (2), the highest score gets the estate with the highest density number from the analysis results. Both high surface permeability (7) and high urban forest continuity (8) can be measured from the proportion of green space. Small and defined blocks (1) is a parameter related to the urban structure. While socialist urban planning was not following the traditional block system of historic towns, it couldn't avoid creating urban unites at a larger sense. Hence, the estates with the more compact and defined blocks/ unites were accessed with higher scores. Multimodal street design (3) increases the efficiency of transportation, encourages walkability and cycling. Ample, free and easily available parking (5) located directly in front of destinations creates a 'pull' towards auto use and can create barriers and uninviting conditions for pedestrians and cyclists (Larco, 2016). High land use mix (4) is more of a 
functional parameter, but it is directly connected to the urban structure of the estates. Platting for the density or organizing of lots (6) of an area can affect mode choice as it often dictates possible building typologies and, in turn, the relationship of buildings to the street (Larco, 2016). Dense/ energy efficient building typologies (9) is a parameter qualified by both of the building density and materials of its construction. Block size/street orientation (10) is defined by the solar orientation of the buildings within the estate and its exposure to the winds (close perimeter of the buildings saves the energy within the estate). Active/attractive open space (11) evaluates the present condition and maintenance of the open public spaces of each housing estate. And finally, mix of unite types (12) indicates the diversity of build-up structure and variation of housing types.

As a result, we can differentiate three categories: Rakéta utcai from the 50's (40 points) and Simon Bolivar from the 70's (42 points), have the best urban form related to sustainability. Interesting to recognize that both estates received architectural award for its masterplans. Therefore, we can say that the urban value, provided by the innovative masterplan has a long-term effect on sustainability. However, the location and building technology of these 2 estates are different. Rakéta utcai was constructed by the traditional brick method on the edge of the city, meanwhile, Simon Bolivar situated not far from Csepel center consists of large prefabricated panel buildings.

Rákóczi block, the contemporary housing development (36 points) and Béke téri, the oldest from the 40 's (32 points) are in the middle position. Both are monofunctional developments with several good architectural qualities related to residential buildings. Rákóczi block became a dense, fenced, mineral part of the city, while Béke téri seems to be actually a neglected "green island" with a lot of potential to become sustainable and livable neighborhood. The last is the Ady úti ( 26 points), a mass production residential project of the 70 's. It is a Large prefabricated estate composed by only two different types of monofunctional residential 10-storey high slabs. In this way, it is possible to say that its actual problems are not only related to the social context but also physical one, presumably on the building and neighborhood levels.

\section{CONCLUSION}

While the methodology of evaluation can be further developed, the research makes it apparent that different urban form has different sustainability quality. In addition, it is important to recognize, that the neighborhood long-term urban quality is not based on the time of construction. It is rather that the lifecycle of a neighborhood is based on permanent changes, whilst the rhythm of buildings, greenery, infrastructure, and residents are not the same. The comparative study shows that architectural and urban qualities are interconnected, and in the case of a housing estates, the urban design value could be one of the most important components of the sustainability.

\section{REFERENCES}

_ Barna, Krisztina. 1995. "Évek, müvek, alkotók". Budapest: Épitésügyi Tájekoztatási Központ Kft.

- Benkő, Melinda. 2015. "Budapest's large prefab housing estates: urban values of yesterday, today and tomorrow" DOI: 10.1556/044.2015.29.1-2.2.

- Benkő, Melinda and Kissfazekas, Kornelia. 2019. "Amoeba Cities". In: Benkő \& Kissfazekas (Eds).: Understanding Post-socialist European Cities. Budapest, Paris: L'Harmattan Publishers pp. 6-26.

- Calthorpe, Peter. 1993. The Next American Metropolis: Ecology, Community, and the American Dream. New York: Princeton Architectural Press.

_ Clapham, David 1995. "Privatisation and East-European housing model", Urban studies journal, vol. 32 (4-5), pp. 679-694. DOI: 10.1080/00420989550012834

_ Engel, Barbara. 2019. Mass housing in a socialist city: heritage, values, and perspectives. p. 26. Berlin: Dom publishers 
_ Frey, Hildebrand. 1999. Designing the City: Towards a More Sustainable Urban Form. London, New York: E \& FN Spon.

- Hough, Michael. 1984. City Form and Natural Process. London: Routledge.

_ Kovács Zoltan, Egedy Tamás, Szabó Balázs. 2018. Persistence or change: divergent trajectories of large housing estates in Budapest, Hungary. In: Hess, D B; Tammaru, T; Ham, M van (szerk.) Housing estates in Europe, Publisher: Springer pp. 191-214.

_ Larco, Nico. 2016. "Sustainable urban design - a (draft) framework", Journal of Urban Design" 21(1), 1-29, DOI: 10.1080/13574809.2015.1071649

_ Petz, Nándor 2017. "Lakótelepek Csepelen". Last modified June 12, 2017. Accessed February 3, 2020. http://www.21 keruleti-hirhatar.hu/index_cikk.php?hh=lakotelepek-csepelen

_ Poklewski-Koziell, Damian. 2015. "The Illusion of Better Living: Comparative Analysis of Prefab Housing Estates with the Contemporary Realizations in Cracow", Periodica Polytechnica Architecture, 46(2), pp. 57-63. DOI: 10.3311/PPar.8957.

_ Salat, Serge. 2011. Cities and forms: on sustainable urbanism. Paris: Editions Hermann, pp 119-120. 